\title{
The learners' writing progress Using Direct Feedback
}

\author{
Tazkiyatunnafs Elhawwa ${ }^{1}$, Dwi Rukmini ${ }^{2}$, Januarius Mujiyanto ${ }^{3}$, Djoko Sutopo \\ \{tazkiyatunnafs.elhawwa@gmail.com¹,wiwidwirukmini@yahoo.com², yanmujiyanto@gmail.com³, \\ djokosutopo_msi@yahoo.com ${ }^{4}$ \}
}

Postgraduate of English Education Department, Universitas Negeri Semarang 1,2,3,4

\begin{abstract}
Written corrective feedback plays an important aspect to increase writing accuracy. The study is to investigate the learners' progress on writing scores: before, during, and after the implementation of teacher direct feedback. The study was conducted at the L2 learners of IAIN Palangka Raya. The study is a quasi-experimental research using repeated measure design. The participants were given three times of tests: before, during and after the implementation of feedback. The data were collected through a writing test. The method of data analysis was used a one-way anova repeated measure. The findings revealed that: (1) Based on the output, there was effect for time, Wilk's Lambda $=0.056, F=1.94, p<0.005$, multivariate eta squared $=0.94$. It was interpreted that there was significant difference on learners' writing progress the treatment. It meant that teacher direct feedback gave significant effects to learners' writing ability for both during and after the treatment and also recommended that the teachers determine the errors to be corrected, the way to correct them and involved the learners so that they could be a part of learning process.
\end{abstract}

Keywords: teacher direct feedback, L2 writing.

\section{Introduction}

For many years, providing feedback to L2 learners is still debatable. Over the years, researchers measured the effects of teacher direct feedback on L2 writers with different results; (Truscott, 2007), for example, viewed that feedback on errors was not a good idea for teaching L2 writing. On the contrary, other researchers such as (Li, 2010), (Russell, \& Spada, 2006), and (Saito, \& Lyster, 2012) believe that feedback contributes important roles in L2 writing. During many years, corrective feedback is seen from different perspectives. In the perspective of behaviorist approach of the 1950s and 1960s, errors were seen as evidence of non-learning and were to be corrected at all cost. In line with this, (Bitchener, \& Ferris, 2012) stated that errors were perceived much more negatively than today's education.

In the early 1970's, communicative approach dominated in L2 learning. Until the end of the 1980s, (Truscott, 2007) suggested that error correction should not occur at all. (Truscott, 1999) powerfully supported that feedback on error does not actually work. Furthermore, (Bitchener, \& Ferris, 2012) proposed questions on the reasons for correcting errors. The other researchers (Bitchener, 2008), (Bitchener, \& Knoch, 2008), (Bitchener, \& Knoch, 2010), (Bitchener, \& Knoch, 2010), (Sheen, 2007), (Van Beuningen, De Jong, \& Kuiken, 2012) stated that impact of teacher direct feedback in helping language learners improve the accuracy in the use of linguistic features. Written corrective feedback contributes significant roles in L2 learning process (Goo \& Mackey, 2011), (Russell \& Spada, 2006), \& (Saito \& 
Lyster, 2012). Furthermore, written corrective feedback allows teachers to give description about the accuracy of learners' production by raising awareness of the grammatical errors in writing.

In the current study, the researcher explores the learners' progress in L2 essay writing class, before, during and after the implementation of teacher direct feedback in L2 writing class. There are some reasons why the study focusing on the learners' progress in L2 writing using teacher direct feedback. First, this study will give empirical data about the teaching of writing, since most students still make grammatical errors when writing an essay. They get difficulties in using grammar correctly. Second, the study will also provide the suitable model of feedback based on the errors they made. Third, giving feedback in 12 writing is still debatable among the experts for example, Truscott $(1996,2004)$ argued that feedback was not useful; meanwhile, Bitchener (2010) said that it was useful and they contributed to learners' language improvement in many ways. This motivates the research to conduct a study exploring the learners' progress in L2 writing using teacher direct feedback. This study will support the theory stating that teacher direct feedback is helpful in L2 writing class and rejecting the theory stating that teacher direct feedback is harmful for L2 learners in L2 writing class. Fourth, based on the preliminary study conducted on December 26, 2017; it was found that the students got difficulties in writing essays. Based on the questionnaire result, most students needed written corrective feedback to improve their writing skills. The problem of the study is: How is the learners' progress in L2 essay writing class: before, during and after the implementation of teacher direct feedback?.

\section{Method}

\subsection{Research Design}

The design of this research is a quasi-experimental research using repeated measure design. The quasi is used since the participants cannot be randomized (Ary, 2010, p. 648). ANOVA Repeated measure is conducted to compare scores at test 1 (before the treatment), test 2 (during the treatment) test 3 (after the treatment) in different period of time (Pallant, 2000, 13).

\subsection{Participants}

In the current research, the participants were the fourth semester L2 students of IAIN Palangka Raya of 2017/ 2018 academic years. The number of participants was 25 L2 learners. There was only one single instrument to collect the data, namely, writing test. The writing score was the main source of data collection. In the present study, the one-way ANOVA repeated measures analysis was considered to be the novelty of the study since the previous studies on the feedback did not use the design. Here, the type and source of feedback used in the study was teacher direct feedback in L2 writing class.

\subsection{Procedures}

To answer the research question, the data were collected through tests. Before the teacher direct feedback being implemented in L2 writing class, the participants were given Test 1 . 
They were assigned to write an argumentative essay as proposed by (Smalley, 2008). Afterward, all participants were given treatment. Here, the teacher practiced Teacher Direct feedback in L2 writing class. The teacher provided the learners with the correct form. In this case, he classified the errors as those classified into language forms, contents and organization. During the implementation of teacher direct feedback, the participants were given Test 2. The aim was to know the learners' progress during the treatment. Finally, after the implementations of the teacher direct feedback, the participants were given Test 3 . Before analysing the data, the assumption test for ANOVA Repeated Measures was conducted, such as testing the normality (Sig.0.348, 0.299, 0.056> p. 0.050, and testing sphericity (Sig. 0.132> p.0.050 (Pallant, 2000, p. 2). A one-way ANOVA Repeated Measures was a statistical computation used to test significant difference or compare three or more group means where the participants were the same in each group (Ary, 2010, p. 636). The repeated measured design was appropriate since the study explored the learners' progress in L2 writing: before, during and after the treatment.

\section{Results and Discussion}

This section dealt with research finding from the statistical calculation analysis.

\subsection{Result from Statistical Calculation}

In order to see the students' progress of writing scores: before, during, and after the implementation of teacher direct feedback in L2 writing class, the result of the three test scores were compared. In the study, the subjects' writing ability was measured three times: before, during, and after the implementation of teacher direct feedback. It was conducted on Friday, March 23, 2018 (before), April 27, 2018 (during) and May 25, 2018 (after). The Learners' Progress in L2 Writing was illustrated in Table 1.

Table 1. The Learners' Progress in L2 Writing

\begin{tabular}{llllllll}
\hline Category & $\begin{array}{l}\text { Score } \\
\text { scale }\end{array}$ & $\begin{array}{l}\text { Test } 1 \\
\text { Number }\end{array}$ & $\%$ & $\begin{array}{l}\text { Test } 2 \\
\text { Number }\end{array}$ & $\%$ & $\begin{array}{l}\text { Test } 3 \\
\text { Number }\end{array}$ & $\%$ \\
\hline Fail & $0-<50$ & 3 & $12 \%$ & 0 & $0 \%$ & 0 & $0 \%$ \\
Poor & $50-<$ & 12 & $48 \%$ & 5 & $24 \%$ & 0 & $0 \%$ \\
Average & $\begin{array}{l}60 \\
\text { 60- }<\end{array}$ & 7 & $28 \%$ & 14 & $56 \%$ & 6 & $24 \%$ \\
Fair & 70 & & & & & & \\
excellent & $70-<$ & 3 & $12 \%$ & 5 & $20 \%$ & 16 & $64 \%$ \\
Total & 80 & & & & & & $12 \%$ \\
& 1.00 & 0 & $0 \%$ & 0 & $0 \%$ & 3 & $100 \%$ \\
\hline
\end{tabular}

Based on the table above, it was seen that in test 1, the participants who got fail category $(0-<50)$ was 3 out of 25 students or $12 \%$; poor category $(50-<60)$ was 12 students or $48 \%$; average score $(60-<70)$ was 7 students or $28 \%$; fair score $(70-79)$ was 3 students or $12 \%$; and there was no participants obtaining excellent score. The average score was in poor 
category (57.04). Then, in Test 2 , the participants who got poor category $(50-<60)$ was 6 out of 25 students or $24 \%$; average score $(60-<70)$ was 14 students or $56 \%$; fair score $(70-79)$ was 5 students or $20 \%$; and there was no participants obtaining excellent score. The average score was in average category (63.56). Finally, in Test 3, the participants who got average score $(60-<70)$ was 6 out of 25 students or $24 \%$; fair score $(70-<80)$ was 16 students or $64 \%$; excellent score (80- 100) was 3 students or $12 \%$; and there were no participants obtaining fail and poor scores. The average score was in fair category (72.88). The progress of the means score is described in figure 1.

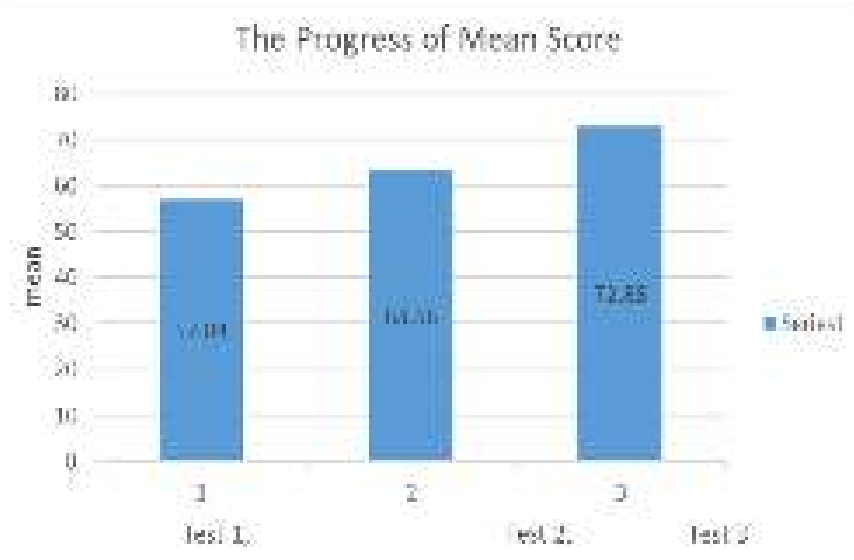

Fig.1. The Progress of Mean Score

\subsection{Testing Hypothesis using One Way ANOVA Repeated Measures}

To analyze the data, the researcher formulated the null hypothesis to be rejected. It was formulated that there was no significant difference on the students' writing progress: before, during, and after the implementation of teacher direct feedback in L2 writing class. Based on descriptive statistics, it was shown that in Test 1, before the implementation of teacher direct feedback, the average score of the students' writing achievement was 57.08 in a 10.00 to 100.00 scales. Then, in Test 2 , during the implementation of TDF, the average score was 63.56 in a 10.00 . This was a slight increase of progress. Moreover, in Test 3, after the implementation of teacher direct feedback, the average score of the class increased dramatically to 72.88 in a 10.00 to 100.00 scales. Comparing with the first test score, this was a sharp increase of progress. The estimated margin of test was as described in Figure 2. 


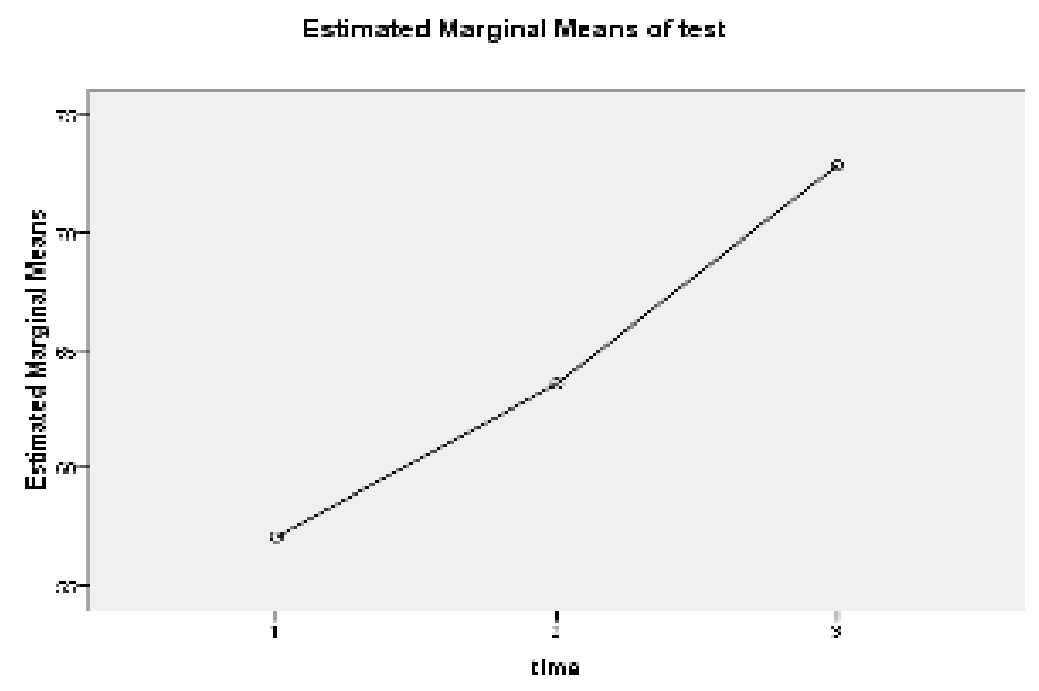

Fig.2. The estimated margin of test

The next step was to see the result of Multivariate Tests as shown in Table 2.

Table 2. Multivariate Tests ${ }^{\mathrm{a}}$

\begin{tabular}{|c|c|c|c|c|c|c|c|}
\hline Effect & & Value & $\mathrm{F}$ & $\begin{array}{c}\text { Hypothe } \\
\text { sis df }\end{array}$ & Error df & Sig. & $\begin{array}{c}\text { Partial Eta } \\
\text { Squared }\end{array}$ \\
\hline \multirow[t]{4}{*}{ time } & Pillai's Trace & .944 & $1.948 \mathrm{E} 2^{\mathrm{a}}$ & 2.000 & 23.000 & .000 & .944 \\
\hline & Wilks' Lambda & .056 & $1.948 \mathrm{E} 2^{\mathrm{a}}$ & 2.000 & 23.000 & .000 & .944 \\
\hline & $\begin{array}{l}\text { Hotelling's } \\
\text { Trace }\end{array}$ & 16.941 & $1.948 \mathrm{E} 2^{\mathrm{a}}$ & 2.000 & 23.000 & .000 & .944 \\
\hline & $\begin{array}{l}\text { Roy's Largest } \\
\text { Root }\end{array}$ & 16.941 & $1.948 \mathrm{E} 2^{\mathrm{a}}$ & 2.000 & 23.000 & .000 & .944 \\
\hline \multicolumn{8}{|c|}{ a. Exact statistic } \\
\hline \multicolumn{8}{|c|}{ b. Design: Intercept Within Subjects Design: time } \\
\hline
\end{tabular}

Based on the multivariate test, it was shown that the sig. Value of Wilks' Lambda was 0.000 . It was less than 0.05 . Therefore the researcher concluded that there was a statistically significant difference for time. This suggested that there was a change in confidence scores across the three different time periods: before, during, and after the implementation of teacher direct feedback in $\mathrm{L} 2$ writing class. 
Table 3. Tests of Within-Subjects Effects

\begin{tabular}{|c|c|c|c|c|c|c|c|}
\hline \multicolumn{8}{|c|}{ Measure test } \\
\hline \multicolumn{2}{|l|}{ Source } & $\begin{array}{c}\text { Type III Sum of } \\
\text { Squares }\end{array}$ & df & Mean Square & $\mathrm{F}$ & Sig. & Partial Eta Squared \\
\hline \multirow[t]{4}{*}{ time } & $\begin{array}{l}\text { Sphericity } \\
\text { Assumed }\end{array}$ & 3168.987 & 2 & 1584.493 & 235.457 & .000 & .907 \\
\hline & $\begin{array}{l}\text { Greenhouse- } \\
\text { Geisser }\end{array}$ & 3168.987 & 1.722 & 1840.220 & 235.457 & .000 & .907 \\
\hline & Huynh-Feldt & 3168.987 & 1.843 & 1719.744 & 235.457 & .000 & .907 \\
\hline & $\begin{array}{l}\text { Lower- } \\
\text { bound }\end{array}$ & 3168.987 & 1.000 & 3168.987 & 235.457 & .000 & .907 \\
\hline \multirow[t]{4}{*}{$\begin{array}{l}\text { Error } \\
\text { (time) }\end{array}$} & $\begin{array}{l}\text { Sphericity } \\
\text { Assumed }\end{array}$ & 323.013 & 48 & 6.729 & & & \\
\hline & $\begin{array}{l}\text { Greenhouse- } \\
\text { Geisser }\end{array}$ & 323.013 & 41.330 & 7.816 & & & \\
\hline & Huynh-Feldt & 323.013 & 44.225 & 7.304 & & & \\
\hline & $\begin{array}{l}\text { Lower- } \\
\text { bound }\end{array}$ & 323.013 & 24.000 & 13.459 & & & \\
\hline
\end{tabular}

Then, the further step was to examine The Tests of Within-Subjects Effects table. It explained if there was an overall significant difference between the means at the different time points. From this table, it was able to discover the $F$ value for the "time" factor, its associated significance level and effect size ("Partial Eta Squared"). It was said that when using an ANOVA with repeated measures with a Greenhouse-Geisser correction, the mean scores for CRP concentration were significantly different $(F(1.722,41.330)=235.457, p<0.0005)$. The results presented that there was an overall significant difference in means of test 1 , test 2 , and test 3 .

Table 4. Tests of Between-Subjects Effects

\begin{tabular}{|c|c|c|c|c|c|c|}
\hline \multicolumn{7}{|c|}{ Measure test Transformed Variable: Average } \\
\hline Source & $\begin{array}{l}\text { Type III } \\
\text { Sum of } \\
\text { Squares }\end{array}$ & $\mathrm{df}$ & $\begin{array}{l}\text { Mean } \\
\text { Square }\end{array}$ & $\mathrm{F}$ & $\begin{array}{c}\text { Sig } \\
\text {. }\end{array}$ & $\begin{array}{l}\text { Partial } \\
\text { Eta } \\
\text { Squared }\end{array}$ \\
\hline $\begin{array}{l}\text { Intercep } \\
\mathrm{t}\end{array}$ & 311954.253 & 1 & $\begin{array}{c}31195 \\
4.253\end{array}$ & $\begin{array}{l}2.06 \\
4 \mathrm{E} 3\end{array}$ & $\begin{array}{c}.00 \\
0\end{array}$ & .989 \\
\hline Error & 3626.747 & 24 & $\begin{array}{c}151.11 \\
4\end{array}$ & & & \\
\hline
\end{tabular}

Based on the Tests of Between-Subjects Effects, it was shown that the value of Eta Squared, given in the multivariate test out put box was 0.989 . Using the guidelines proposed by Cohen, $1988(01=$ small, $0.06=$ moderate, 0.14 large effect $)$, this result suggested a very large effect size.

Based on the out put, it was said that there was effect for time, Wilk's Lamda $=0.056, \mathrm{~F}=$ $1.94, p<0005$, multivariate eta squared $=0.94$. Based on the above statistical calculation, it was interpreted that there was significant difference on the students' writing progress: before 
(mean=57.04), during $($ mean=63.56), and after $($ mean= 72.88$)$ the implementation of teacher direct feedback in L2 writing. It meant that teacher direct feedback gave significant effects to the students' writing ability in writing argumentative essay for both during and after the implementation of teacher direct feedback.

\section{Conclusion}

Based on the out put, it was said that teacher direct feedback gave significant effects to the students' writing ability in writing argumentative essay for both during and after the teacher direct feedback implementation.

This finding was in accordance with a study conducted by (Karim, 2013). The findings of Karim's study suggested that both direct and indirect corrective feedback could significantly improve both grammatical and non-grammatical accuracy. This finding was also in line with other researchers. For example, (Sheen, 2010) revealed that the written direct correction showed greater effects than oral recast in helping learners improve their grammatical accuracy. Some of the researchers (Bitchener \& Knoch, 2010), (Chandler, 2003), and (Van Beuningen, 2010) also claimed that direct corrective feedback enables learners to instantly internalize the correct form as provided by their teacher. (Evans, 2012) also found that direct unfocused teacher direct feedback can be effective in improving accuracy. Moreover, providing different systems of error and feedback categorization to help research the properties of language teachers' feedback outcome in student papers (Jodaie, Farrokhi, \& Zoghi, 2011).

The findings of the study proposed some considerations regarding written corrective feedback in L2 writing class that might be beneficial for L2 writing teachers. To begin with, L2 learners should be made aware of the importance of receiving feedback. Therefore, L2 writing teachers should explain the L2 learners about the whole procedure and set the goals together with the learners. Moreover, teachers should determine, which errors they wanted to correct, how they wanted to correct them and when they were planning to make the correction and involved the learners so that they could be a part of the process. Furthermore, the teachers' feedback should be clear that when learners understand to the teachers' want. Finally, L2 teachers should monitor the learners during the process of correction in order to observe their language development in L2 writing class. As this research was conducted with only 25 L 2 writing learners, it was not very likely to generalize about the findings. Therefore, further researches might work with greater number participants so that they could reach at conclusions that are more generalizable. Another recommendation for future researcher was to conduct the same or a similar study with a different level of students. Since this study was carried out with university level of students, it was recommended to conduct a similar study with senior high school level of students. 


\section{References}

[1] Ary, Donald, Lucy,C.J. Chris, S, and Asghar R.: Introduction to Research in Education (Eighth edition). United States: Wadsworth Cengage Learning (2010)

[2] Bitchener, J.: Evidence in support of written corrective feedback. Vol 17 (2), pp. 102-118. Journal of Second Language Writing (2008)

[3] Bitchener, J., \& Ferris, D. R.: Research on written cf in language classes. In Written Corrective Feedback in Second Language Acquisition and Writing, pp. 49-74 (2012).

[4] Bitchener, J and Knoch U.: The value of written corrective feedback for migrant and international students. Language Teaching Research, Vol 12 (3), pp 409-431 (2008)

[5] Bitchener, J., \& Knoch, U. Raising the linguistic accuracy level of advanced L2 writers with written corrective feedback. Vol. 19 (4), pp. 207-217. Journal of Second Language Writing (2010)

[6] Bitchener, J and Knoch U.: The contribution of written corrective feedback to language development: A ten-month investigation. Applied Linguistics, Vol. 31 (2), pp 193-214 (2010)

[7] Chandler, J.: The efficacy of various kinds of error feedback for improvement in the accuracy and fluency of L2 student writing. Journal of Second Language Writing, Vol. 12 (3), pp 267-296 (2003)

[8] Evans, K. J.: The differential effects of comprehensive corrective feedback on L2 writing accuracy. Vol. 3 (2), pp. 217-248. Journal of Linguistics and Language Teaching (2012)

[9] Jodaie, Mina., Farrokhi, Farahman., \& Zoghi, Masoud.: (2011). A comparative study of EFL teachers' and intermediate high school students' perceptions of written corrective feedback on grammatical errors. Vol. 4 (4), pp. 36-48. English Language Teaching (2011)

[10] Karim, Khaled.: The effects of direct and indirect written corrective feedback (CF) on Englishas-a-second- language (ESL) students' revision accuracy and writing skills. University of Victoria In the Department of Linguistics (2013).

[11] Li, S.: The effectiveness of feedback in SLA: A Meta-Analysis. Language Learning (2010)

[12] Pallant, Julie F.: SPSS Survival Manual: A Step by Step guide to data analysis using SPSS, Monash: Monash University (2000).

[13] Russell, J and Spada, N.: The effectiveness of feedback for the acquisition of L2 grammar. Synthesizing Research on Language Learning and Teaching, pp. 133-164 (2006)

[14] Saito, K and Lyster, R.: Effects of form-focused instruction and feedback on L2 pronunciation development of /r\{turned \}/ by Japanese Learners of English. Language Learning, Vol 62 (2), pp 595$633(2012)$

[15] Sheen, Y.: The effect of focused written corrective feedback and language aptitude on ESL learners' acquisition of articles. TESOL Quarterly, Vol 41 (2), pp. 255-283 (2007)

[16] Sheen, Y.. Differential effects of oral and written corrective feedback in the ESL classroom. Vol. 32 (2), pp. 203-234. Studies in Second Language Acquisition (2010)

[17] Smalley, L. R.: Refining composition skills. Harvard Business Review (2008)

[18] Truscott, J.: Evidence and conjecture on the effects of correction: A response to Chandler. Journal of Second Language Writing (2004)

[21] Truscott, J.: The effect of error correction on learners' ability to write accurately. pp. 255-272. Journal of Second Language Writing (2007)

[22] Truscott, J.: Arguments and appearances: A response to Chandler. Journal of Second Language Writing (2009)

[23] Van Beuningen, C.. Corrective feedback in L2 writing: theoretical perspectives, empirical insights, and future directions. Vol. 10 (2). pp. 1-27. IJES (2010)

[24] Van Beuningen, C. G., De Jong, N. H., \& Kuiken, F.: Evidence on the effectiveness of comprehensive error correction in second language writing. Vol. 62 (1). pp. 1-41. Language Learning (2012) 